\title{
Pengaruh penggunaan tepung limbah udang fermentasi terhadap karakteristik organ reproduksi pada puyuh petelur (Coturnix coturnix japonica)
}

\author{
Welda Hilkias, Edjeng Suprijatna, Yon Soepri Ondho \\ Fakultas Peternakan dan Pertanian Universitas Diponegoro Semarang \\ Corresponden author :weldahilkias16@gmail.com
}

\begin{abstract}
The aim of the present study was to evaluate the effect of fermented shrimp waste meal on the characteristics of reproductive organs such as live weight, oviduct weight and length, ovarian weight, total yellow follicles, total white follicles, oviduct percentage and reproductive organ percentage. This experiment was conducted on Faculty of Animal Science and Agriculture, Diponegoro University. A total of 250, 6-week-old Japanese quail (consist of 250 females) were randomly assigned to one of 5 dietary treatments. 1st group (T0) was fed by diet without shrimp waste (control), 2nd group (T1) was fed by diet with $7,5 \%$ non-fermented shrimp waste, 3rd group (T3) was fed by diet with $5 \%$ fermented shrimp waste (FSW), 4th group (T3) was fed by diet with 7,5\% FSW and 5th group was fed by diet with $10 \%$ FSW. 2 quails from each replicates were taken as samples. The members of a given sample were killed by severing the neck then separated the reproductive organs from the body. Measured the live weight, oviduct weight and length, ovarian weight, total yellow follicles, total white follicles, oviduct percentage and reproductive organ percentage. All data were examined using analysis of variance (ANOVA). The results showed that the effect of fermented shrimp waste meal on reproductive organs characteristics such as live weight, oviduct weight and length, ovarian weight, total yellow follicles, total white follicles, oviduct percentage and reproductive organ percentage were not significant. The use of fermented shrimp waste up to $10 \%$ didn't obstruct the growth and development of quail reproductive organs.
\end{abstract}

Keywords: Japonica quailI, fermented shrimp waste, characteristics of reproductive organs

\section{PENDAHULUAN}

Pesatnya pertumbuhan puyuh di Indonesia disebabkan oleh tingginya minat masyarakat karena puyuh cepat bertelur. Produksi telur puyuh yang tinggi dapat menjadikannya suplementasi telur ayam. Kandungan protein telur puyuh cukup tinggi yaitu $13,35 \%$ (Ketaren, 2007), lebih tinggi dari telur ayam dan itik yaitu $12,14 \%$ dan 12,81\% (Chen,
1996). Pemeliharaan puyuh petelur memiliki kendala yaitumembutuhkan bahan pakan tinggi protein yang mahal harganya sehingga perlu alternatif sumber protein yang murah, tidak bersaing dengan manusia, ketersediaanya tinggi dan kandungan nutrisinya tinggi. Alternatif bahan pakan yang dapat digunakan salah satunya adalah limbah udang. 
Limbah udang adalah sisa hasil industri pengulitan udang yang terdiri dari kepala, kulit (cangkang) dan kaki. Produksi limbah udang di Indonesia mencapai 141.040 ton/tahun, 4\% dari produksi udang 352.600 ton/tahun (Direktorat Jendral Budidaya Departemen Kelautan dan Perikanan, 2010). Kandungan limbah udang yaitu protein kasar 36,75\%, lemak kasar 5,72\%, serat kasar 14,49\%, Ca (kalsium) 13,99\% dan $\mathrm{P}$ (fosfor) 1,28\% (Palupi, 2005). Selain memiliki kelebihan, limbah udang juga memiliki kelemahan sebagai pakan karena mengandung kitin yang cukup tinggi yang bersifat sulit dicerna. Kitin adalah biopolimer dari unit N-asetil-Dglukosamin bewarna putih, tidak berasa, tidak berbau dan tidak larut air, pelarut organik umumnya, asam-asam anorganik dan basa encer (Rahayu dan Purnavita, 2007). Kitin mengikat N dari asam amino penyusun protein sehingga protein menjadi sulit dicerna. Salah satu cara untuk menguraikan kitin adalah dengan enzim kitinase yang dapat menghidrolisa senyawa polimer kitin menjadi kitin oligosakarida (monomer N-asetil glukosamin) (Pratiwi dkk., 2015). Penelitian sebelumnya yang dilakukaan oleh Palupi dan Imsya (2011) menggunakan Trichoderma viridauntuk fermentasi tepung limbah udang dan menunjukan hasil terbaik pada penggunaan inokulum $4 \%$ dengan waktu fermentasi 48 jam yang dapat meningkatkan kadar menjadi protein $41,27 \%$, daya cerna protein $81,24 \%$ serta kandungan kitin menjadi 3,01\%. Pengolahan kitin dengan menggunakan Trichoderma $s p$ produk komersil dapat menurunkan kitin dari $12 \%$ menjadi 11\%.Limbah udang juga mengandung kitosan (Saenab et al., 2010). Kitosan dalam bentuk FERMKIT (fermented chitin-chitosan) dapat meningkatkan perkembangan oviduk (Khajarern et al.,2003).

Protein pada tubuh puyuh telur dimanfaatkan sebagai bahan pembentukan hormon GnRh, LH dan FSH serta penyusun folikel yang akan berkembang menjadi yolk. GnRh (gonadotropin-releasing hormone) adalah hormon reproduksi yang diproduksi oleh hipotalamus (Dunn et al., 1993; Ikemoto dan Park, 2006) yang tersusun atas asamasam amino seperti histidin, triptofan dan serin serta gugus $\mathrm{NH}_{2}$ (King and Millar, 1982). Fungsi GnRH yaitu menstimulasi kelenjar pituitari untuk memproduksi hormon LH (luteinizing hormone) dan hormon FSH (follicle-stimulating hormone) (Ottinger dan Bakst, 1995). Hormon LH dan FSH tersusun atas glikoprotein (Burke et al., 1979). Fungsi dari hormon LH adalah mempengaruhi produksi faktor-faktor pertumbuhandan hormon-hormon dalam ovarium sama seperti FSH (Scanes, 2006) serta menyebabkan ovulasi folikel (Imai,1973). Tugas dari hormon FSH dalam sistem reproduksi unggas adalah menstimulasi pedewasaan sel granulosa dari folikelfolikel kecil (Tilly et al, 1991). Protein juga dibutuhkan dalam bentuk lipoprotein untuk pematangan folikel (Scanes, 2006). Bertambahnya protein yang membantu dalam perkembangan folikel, diharapkan akan mempercepat ovulasi folikel yang kemudian menjadi yolk sehingga meningkatkan produksi telur.

Tujuan dari penelitian ini adalah mengetahui pengaruh penggunaan limbah udang fermentasi terhadap karakteristik organ reproduksi puyuh petelur meliputi bobot hidup, panjang dan bobot oviduk, jumlah folikel kuning, bobot ovarium, bobot folikel kuning dan putih, persentase oviduk dan persentase organ reproduksi. 
Manfaat dari penelitian ini adalah mendapat jumlah penggunaan TLUF yang optimalmempengaruhi karakteristik organ reproduksi puyuh petelur meliputi bobot hidup, panjang dan bobot oviduk, jumlah folikel kuning, bobot ovarium, bobot folikel kuning dan putih, persentase oviduk dan persentase organ reproduksi.

\section{METODOLOGI}

Penelitian dilaksanakan pada bulan November - Januari 2016 di Kandang Unggas, Fakultas Peternakan dan Pertanian Diponegoro, Semarang.

\section{Materi penelitian}

Puyuh petelur sebanyak 250 ekor dengan bobot $141 \pm 9,58$ gram dengan umur 6 minggu, limbah udang yang terdiri dari kepala, cangkang dan kaki, Trichoderma sp. produk komersil sebagai fermentator, timbangan analitis, pita ukur, tempat fermentasi, dan kandang.

\section{Metode Penelitian}

Metode penelitian terdiri dari 2 tahap, persiapan dan pelaksanaan. Tahap persiapan dengan mengambil limbah udang diambil dari industri pengulitan udang dicuci dengan air mengalir hingga bersih. Limbah udang yang telah bersih dikukus selama 45 menit sampai berubah warna kemudian ditiriskan. Fermentasi menggunakan produk komersil Trichoderma sp. yang mengandung 3 jenis kapang Trichoderma. Pembuatan dengan $1 \mathrm{~kg}$ limbah udang, membutuhkan $500 \mathrm{ml}$ air dan $20 \mathrm{ml}$ Trichoderma. Mencampur rata limbah udang dengan Trichoderma air kemudian memasukan dalam tempat kedap udara. Letakkan di tempat yang jauh dari sinar matahari dan biarkan selama 48 jam sampai terjadi perubahan warna. Buka tempat fermentasi dan keringkan limbah udang hingga kering udara kemudian dihaluskan hingga menjadi tepung. Menguji kadar kitin dalam limah udang fermentasi dengan hasil yang tertera pada tabel 1 .

Tabel 1. Hasil analisis kandungan kitin

\begin{tabular}{lc}
\hline & Kandungan \\
\hline Limbah udang non fermentasi $(\%)$ & 12 \\
Limbah udang fermentasi $(\%)$ & 11 \\
\hline
\end{tabular}

Laboratorium Pengujian, Institut Pertanian Bogor, 2016.

Tahap pelaksanaan yaitu membagi 250 puyuh petelur berumur 6 minggu dengan kisaran bobot $141 \pm 9,58$ sesuai 5 ransum perlakuan yang diberikan. Ransum perlakuan T0 yaitu pakan tanpa limbah udang, T1 yaitu pakan dengan tepung limbah udang non fermentasi (TLUNF), T2 yaitu pakan dengan tepung limbah udang fermentasi (TLUF) sebanyak 5\%, dan T3 yaitu pakan dengan TLUF sebanyak 7,5\% dan T4 dengan TLUF sebanyak $10 \%$ dengan kandungan ransum tiap perlakuan yaitu jagung, bekatul, bungkil kedelai, MBM, kapur dolomit, premix, metionin dan lisin yang dapat dilihat pada Tabel 2 dan tabel 3. 
Tabel 2. Komposisi bahan pakan tiap ransum perlakuan

\begin{tabular}{|c|c|c|c|c|c|}
\hline Bahan pakan & T0 & $\mathrm{T} 1$ & $\mathrm{~T} 2$ & $\mathrm{~T} 3$ & $\mathrm{~T} 4$ \\
\hline & \multicolumn{5}{|c|}{-----------------------------\%\%-------------------------------- } \\
\hline Jagung & 57.6 & 53.2 & 53.7 & 50.3 & 47.2 \\
\hline Bekatul & 5.1 & 6.9 & 6.4 & 9.8 & 11.5 \\
\hline Bungkil Kedelai & 28 & 24 & 25 & 23.5 & 23.5 \\
\hline TLUF & 0 & 0 & 5 & 7.5 & 10 \\
\hline TLUNF & 0 & 7.5 & 0 & 0 & 0 \\
\hline MBM & 7 & 7 & 7 & 6 & 4.4 \\
\hline lysin & 0.05 & 0.05 & 0.1 & 0.1 & 0.3 \\
\hline Methionin & 0.05 & 0.05 & 0.1 & 0.1 & 0.2 \\
\hline Kapur dolomit & 2 & 1 & 1.7 & 1.7 & 1.4 \\
\hline Premix & 0.2 & 0.3 & 1 & 1 & 1.5 \\
\hline Total & 100 & 100 & 100 & 100 & 100 \\
\hline
\end{tabular}

Laboratorium Teknologi Pakan Universitas Diponegoro, 2016

Tabel 3. Kandungan nutrisi tiap ransum perlakuan

\begin{tabular}{|c|c|c|c|c|c|}
\hline Kandungan & T0 & $\mathrm{T} 1$ & $\mathrm{~T} 2$ & T3 & $\mathrm{T} 4$ \\
\hline Energi Metabolis $(\mathrm{kkal} / \mathrm{kg})^{1}$ & 2777.85 & 2814,11 & 2821.99 & 2824,04 & 2778,37 \\
\hline Protein Kasar $(\%)^{2}$ & 21,54 & 22,35 & 22,35 & 22,45 & 21,95 \\
\hline Serat Kasar $(\%)^{2}$ & 3,16 & 4,11 & 4,77 & 5,35 & 4,26 \\
\hline Lemak Kasar $(\%)^{2}$ & 6,79 & 6,83 & 6,85 & 6,53 & 6,78 \\
\hline Kalsium $(\mathrm{Ca})(\%)^{2}$ & 2,71 & 3,27 & 3,59 & 3,57 & 2,98 \\
\hline Fosfor $(\mathrm{P})(\%)^{2}$ & 0,65 & 0,78 & 0,84 & 0,85 & 0,84 \\
\hline $\operatorname{Lisin}(\%)^{3}$ & 1,49 & 1,5 & 1,43 & 1,54 & 1,45 \\
\hline Metionin $(\%)^{3}$ & 0,61 & 0,65 & 0,64 & 0,74 & 0,61 \\
\hline
\end{tabular}

Sumber : ${ }^{1}$ Hasil Analisis di Laboratorium PT. Sidomuncul, 2016.

${ }^{2}$ Hasil Analisis di Laboratorium Ilmu Nutrisi dan Pakan, Universitas Diponegoro

${ }^{3}$ Label kemasan feed supplement

Pengambilan sampel dengan cara menekropsi puyuh petelur berumur 1 minggu untuk diambil dan diamati organ reproduksinya. Bobot saluran reproduksi diperoleh dari penimbangan oviduk dari ismus hingga kloaka. Panjang saluran reproduksi dihitung dengan cara membentangkan saluran reproduksi dari ismus hingga kloaka dan mengukurnya dengan pita ukur. Jumlah folikel kuning diperoleh dengan menghitung jumlah yolk yang belum diovulasikan yang telah berwarna kuning. Bobot folikel kuning diambil dari penimbangan yolk yang belum diovulasikan yang telah berwarna kuning dengan timbangan analitis. Bobot folikel putih diambil dari penimbangan yolk yang belum diovulasikan yang telah berwarna putih dengan timbangan analitis. Bobot ovarium dihitung dengan menambahkan bobot folikel warna kuning dengan folikel warna putih (dengan selaput ovarium). Persentasi 
oviduk dihitung dengan rumus yang

digunakan oleh Sahara (2010).

bobot saluran reproduksi

bobot hidup $\times 100$

Persentase organ reproduksi dihitung dengan rumus

bobot folikel putih+bobot folikel kuning+bobot saluran reproduksi

bobot hidup

$\times 100$

Data yang didapat kemudian dianalisis dengan analisis ragam (ANOVA) dan di uji F untuk mengetahui adanya pengaruh oleh perlakuan. Apabila terdapat pengaruh oleh perlakuan, dilanjutkan dengan Uji Duncan.

\section{HASIL DAN PEMBAHASAN}

Berdasarkan penelitian yang dilakukan, diperoleh hasil yang dapat dilihat pada Tabel 4 dengan ilustrasi organ reproduksi puyuh peteluryaitu ovarium dan oviduk dapat dilihat di Ilustrasi 1.

Tabel 4. Parameter pengamatan

\begin{tabular}{lcccccc}
\hline \multirow{2}{*}{ Parameter } & \multicolumn{5}{c}{ Perlakuan } & \multirow{2}{*}{ Keterangan } \\
\cline { 2 - 6 } Bobot Hidup & $\mathrm{T} 0$ & $\mathrm{~T} 1$ & $\mathrm{~T} 2$ & $\mathrm{~T} 3$ & $\mathrm{~T} 4$ & \\
(gram) & $151,3 \pm$ & $154,3 \pm$ & $148,5 \pm$ & $156,3 \pm$ & $153,8 \pm$ & $\mathrm{ns}$ \\
Bobot Saluran & 4,82 & 20,5 & 12,44 & 5,74 & 11,12 & \\
Reproduksi (gram) & $0,674 \pm$ & $6,362 \pm$ & $6,554 \pm$ & $7,245 \pm$ & $6,127 \pm$ & $\mathrm{ns}$ \\
Panjang Saluran & $26,57 \pm$ & 0,64 & 2,24 & 0,89 & 0,7 & \\
Reproduksi (cm) & 3,86 & 1,9 & 3,63 & 0,37 & 4,92 & $\mathrm{~ns}$ \\
& $4,585 \pm 2$, & $4,210 \pm$ & $3,713 \pm$ & $5,015 \pm$ & $3,790 \pm$ & $\mathrm{ns}$ \\
Bobot Ovarium & 18 & 1,51 & 0,59 & 1,97 & 1,38 & \\
& $3,6 \pm$ & $3,9 \pm$ & $3,3 \pm$ & $3,7 \pm$ & $3,3 \pm$ & $\mathrm{ns}$ \\
Jumlah Folikel & 0,42 & 1,56 & 0,76 & 0,91 & 0,97 & \\
Kuning (butir) & $3,736 \pm$ & $4,166 \pm$ & $3,238 \pm$ & $4,509 \pm$ & $3,302 \pm$ & $\mathrm{ns}$ \\
Bobot Folikel & 1,53 & 2,16 & 0,66 & 2,1 & 1,34 & \\
Kuning (gram) & $0,474 \pm$ & $0,419 \pm$ & $0,475 \pm$ & $0,506 \pm$ & $0,488 \pm$ & $\mathrm{ns}$ \\
Bobot Folikel Putih & 0,07 & 0,04 & 0,1 & 0,16 & 0,08 & \\
(gram) & $4,403 \pm$ & $4,229 \pm$ & $4,441 \pm$ & $4,650 \pm$ & $3,978 \pm$ & $\mathrm{ns}$ \\
Persentase Saluran & 4,56 & 0,4 & 1,48 & 0,63 & 0,61 & \\
Reproduksi (\%) & $0,56,9,91 \pm$ & $23,43 \pm$ & \\
Persentase Organ & $7,208 \pm$ & $7,256 \pm$ & $6,957 \pm$ & $7,889 \pm$ & $6,404 \pm$ & $\mathrm{ns}$ \\
Reproduksi (\%) & 1,12 & 1,57 & 1,56 & 1,82 & 1,52 & \\
\hline
\end{tabular}

ns : tidak signifikan $(\mathrm{P}>0,05)$ 


\section{Bobot hidup}

Dilihat dari data pada Tabel 4, penggunaan TLUF tidak signifikan menambah bobot hidup. Dampak ransum perlakuan yang kurang optimal untuk meningkatkan bobot hidup disebabkan oleh kitin dalam pakan yang sulit dimanfaatkan puyuh. Hal ini sependapat dengan Suryaningsih dan Parakkasi (2006) bahwa kitin merupakan serat kasar yang sulit dicerna. Kitin dapat mengikat zat-zat nutrisi yang dibutuhkan untuk pertumbuhan ternak sehingga apabila tidak diuraikan zat-zat nutrisi tersebut tidak bisa diserap secara otimal oleh tubuh ternak. Castro et al. (1989) menambahkan bahwa kitin mengurangi kinerja enzim pencernaan terhadap lemak dan protein.

Hasil berbeda ditunjukan pada penelitian Djunaedi (2009) yang menunjukan penggunaan TLUF pada ayam broiler dapat meningkatkan bobot hidup akhir secara signifikan. Perbedaan hasil tersebut disebabkan karena proporsi bagian limbah udang yang berbeda dalam TLUF sehingga kandungan nutrisinya pun berbeda. Sebab lain adalah persentase penggunaan limbah udang yang diduga terlalu tinggi. Hal ini didukung oleh pendapat Khempaka et al. (2006) bahwa penggunaan limbah udang sebagai pakan hingga $8 \%$ dapat menurunkan pertambahan bobot badan sehingga disarankan batas penggunaannya sebesar $4 \%$ untuk ayam broiler.

\section{Panjang dan bobot saluran reproduksi}

Berdasarkan data panjang dan bobot saluran reproduksi puyuh petelur pada Tabel 4, ransum perlakuan terbukti tidak menghambat pertumbuhan oviduk yang ditunjukan oleh data analisis yang tidak signifikan. Hasil yang sama juga terjadi pada penelitian Sahara (2010) yang menunjukkan bahwa pemberian limbah udang tidak menunjukan hasil yang signifikan pada bobot oviduk itik. Hal ini terjadi karena kecernaan protein yang juga tidak signifikan. Protein digunakan untuk pertumbuhan sel pada organ dalam tubuh. Panjaitan et al. (2012) menambahkan bahwa pertumbuhan organ reproduksi tersebut dibentuk dengan protein sebagai bahan utama yang nantinya berpengaruh pada produksi pada fase layer, apabila konsumsi protein kurang dapat menyebabkan gangguan perkembangan organ reproduksi.

Faktor lain yang menyebabkan tidak berpengaruhnya perlakuan pada ternak adalah telah berhentinya pertumbuhan organ reproduksi atau puyuh telah mengalami dewasa kelamin sehingga puyuh hanya bisa memanfaatkan protein pakan selama 4 minggu dari umur 5 minggu hingga 9 minggu. Sesuai dengan pendapat Scanes (2006) bahwa dewasa kelamin pada puyuh jantan terjadi pada umur 5-6 minggu dan puyuh betina mulai bertelur pada umur 9-10 minggu, pertumbuhan oviduk terjadi dibawah pengaruh hormon estradiol dan progesteron dengan meningkatnya sintesis protein. Kurangnya kandungan kitosan pada tepung limbah udang fermentasi juga menjadi salah satu faktor tidak berpangurahnya perlakuan pada oviduk. Kitosan dapat mempercepat pertumbuhan oviduk. Penelitian yang dilakukan Khajarern et al. (2003) menunjukan bahwa FERMKIT (probiotik fermentasi yang terbuat dari kitin, kitosan dan kitin oligosakarida) dapat meningkatkan perkembangan oviduk. 


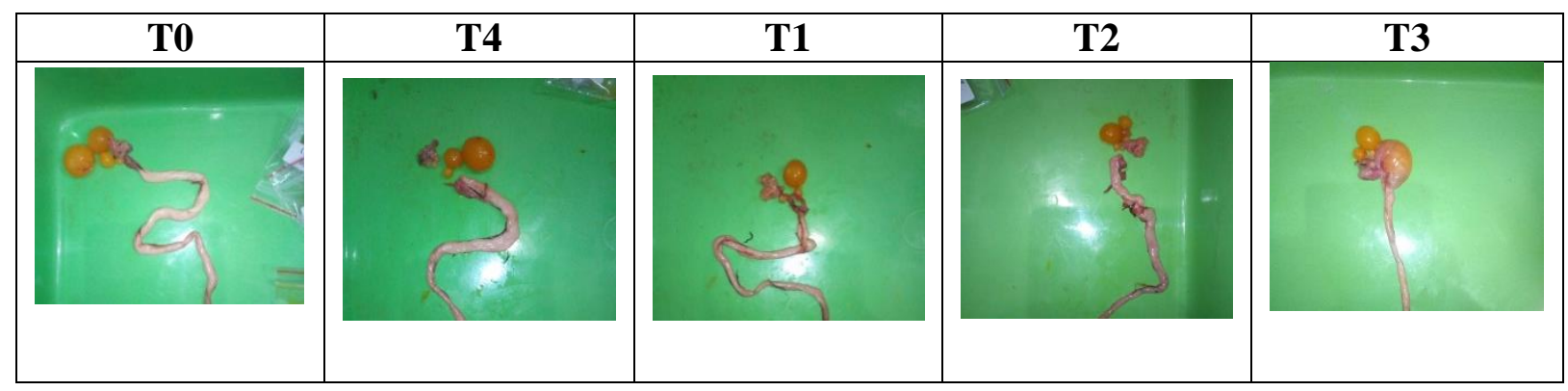

Gambar 1. Reproduksi puyuh petelur

\section{Bobot Ovarium}

Terjadi peningkatan pada T3 namun tidak signifikan. Hasil yang sama ditunjukan dalam penelitian Sahara (2010) bahwa pemberian limbah udang dan daun kaliandra tidak berpengaruh nyata terhadapa persentase ovarium. Penyebab kurang optimalnya efek penggunaan TLUF pada pertumbuhan ovarium adalah protein ransum kurang optimal dimanfaatkan oleh puyuh yang dapat dilihat dari tidak signifikannya kecernaan protein. Protein digunakan sebagai pertumbuhan dan perkembangan folikel dan hormon FSH yang berfungsi untuk perkembangan folikel pada ovarium. Hal ini sesuai dengan pendapat In et al. (2016) menambahkan bahwa susunan yolk adalah lemak (65-70\% dalam BK) dan protein (30\% dalam BK) yang merupakan padatan sertalivetin dan lipoprotein.

Faktor lain yang mempengaruhi adalah kadar kitosan yang rendah pada TLUF, terbukti dari tingginya kitin (bahan pembentuk kitosan) sehingga tidak menambah bobot ovarium secara signifikan. Kitosan dapat meningkatkan viabilitas sel sehingga dapat menjamin kelangsungan hidup sel ovarium hingga matang. Menurut penelitian Boca et al., 2010 menunjukan bahwa kitosan terproteksi nanopartikel emas (AuNPs) memiliki dampak minimal pada morfologi dan peningkatan viabilitas sel ovarium Hamster Cina (HCO).

\section{Jumlah dan bobot folikel warna kuning}

Berdasarkan data yang diperoleh, terjadi fluktuasi pada jumlah dan bobot folikel berwarna kuning. Peningkatan terjadi pada T1 dan T3, jumlah folikel warna kuning tertinggi pada T1 3,9 butir dan bobot folikel warna kuning tertinggi pada T3 4,509 gram. Peningkatan jumlah dan bobot folikel warna kuning tidak berbeda nyata. Hal ini terjadi karena dampak penggunaan TLUF dalam ransum terhadap kecernaan protein tidak nyata. Protein sangat diperlukan pada pertumbuhan folikel sebagai bahan pembentukan folikel prehierarchalpreovulotory (folikel kuning). yang mengandung vitellogenin dan VLDL (very low densitylipoprotein) sehingga apabila protein pada tubuh puyuh rendah, pertumbuhan folikel preovulotory akan terhambat dan tidak bisa diovulasikan. Hal ini sesuai dengan pendapat Scanes (2006) bahwa saat perkembangan folikel preovulotory dimulai, sel granulosa menjadi lunak untuk memudahkan penyerapanvitellogenin dan VLDL dalam jumlah besar. In et al. (2016) menambahkan bahwa susunan yolk adalah lemak (65 - $70 \%$ dalam BK) dan protein $(30 \%$ dalam $\mathrm{BK})$ yang 
merupakan padatan serta livetin dan lipoprotein.

Penyebab lain yang mempengaruhi kurang berpengaruhnya ransum perlakuan terhadap jumlah dan bobot folikel warna kuning adalah kandungan kitosan yang rendah yang ditunjukan oleh tingginya kitin yang merupakan bahan pembentuk kitosan dalam ransum perlakuan. Kitosan membantu tumbuh kembang sel-sel ovarium yang terdiri dari banyak folikel warna kuning dan putih. Berdasarkan penelitian yang dilakukan Boca et al., 2010 menunjukan bahwa kitosan terproteksi nanopartikel emas (AuNPs) memiliki dampak minimal pada morfologi dan peningkatan viabilitas sel ovarium Hamster Cina (HCO).

\section{Bobot folikel warna putih}

Bobot folikel mengalami peningkatan tertinggi pada $\mathrm{T} 2$ yaitu 0,506 gram kemudian menurun pada $\mathrm{T} 4$. Kenaikan yang terjadi tidak signifikan. Hal ini terjadi karena efisiensi dan retensi protein erlakuan tidak berbeda nyata. Protein digunakan untuk menyusun hormon FSH dan LH yang berfungsi untuk perkembangan folikel. Menurut Burke et al. (1979) LH dan FSH tersusun atas glikoprotein. Hormon LH memacu perkembangan folikel primordial menjadi folikel putih (primary follicel) yang ditandai dengan pembentukan theca interna. Tilly dan Johnson (1989) menambahkan bahwa mekanisme sinyal transduksi dimana LH menekankan pengaruhnya pada LH terjadi via adenylate cyclase dan cAMP .

Tingginya kitin sebagai bahan pembuat kitosan, menunjukkan rendahnya kitin yang dapat diubah menjadi kitosan. Kitosan berperan meningkatkan tumbuh kembang sel-sel ovarium yang terdiri dari banyak folikel warna kuning dan putih. menurut penelitian yang dilakukan Boca et al., kitosan terproteksi nanopartikel emas (AuNPs) memiliki dampak minimal pada morfologi dan peningkatan viabilitas sel ovarium Hamster Cina (HCO).

\section{Persentase saluran reproduksi (oviduk hingga kloaka) dan organ reproduksi (oviduk hingga kloaka dan ovarium)}

Berdasarkan data yang diperoleh, terjadi fluktuasi pada persentase oviduk dan persentase organ reproduksi dengan nilai tertinggi pada T3 yaitu 4,650\% dan $7,889 \%$. Kenaikan pada persentase oviduk dan persentase organ reproduksi tidak signifikan karena kecernaan protein yang tidak berbeda nyata. Panjaitan dkk, (2012) menambahkan bahwa pertumbuhan organ reproduksi tersebut dibentuk dengan protein sebagai bahan utama yang nantinya berpengaruh pada produksi pada fase layer, apabila konsumsi protein kurang dapat menyebabkan gangguan perkembangan organ reproduksi. Faktor lainnya adalah bobot ovarium, oviduk dan bobot hidup yang tidak berbeda nyata. Bobot hidup tidak signifikan terjadi akibat konversi pakan yang juga tidak signifikan sehingga berpengaruh pada persentase oviduk dan organ reproduksi. Konversi pakan berhubungan dengan konsumsi dan massa telur. Yuwanta (2003) menambahkan bahwa konversi pakan pada unggas petelur yaitu perbandingan antara konsumsi pakan dengan produksi telur dikali rata-rata bobot telur.

\section{KESIMPULAN}

Hasil penelitian menunjukan bahwa penggunaan tepung limbah udang fermentasi dapat digunakan hingga level $10 \%$ karena tidak menggangu 
pertumbuhan perkembangan dan karakteristik organ reproduksi puyuh petelur.

\section{UCAPAN TERIMA KASIH}

Ucapan syukur penulis ucapkan pada Tuhan Yang Maha Esa karena telah memperlancar penulisan jurnal. Penulis juga mengucapkan terima kasih kepada dosen-dosen pembimbing dan rekanrekan penilitian yang membantu penulisan dan penelitian.

\section{DAFTAR PUSTAKA}

Boca, S. C., M. Potara, F. Toderas, O. Stephan, P. L. Baldeck, S. Astilean. 2010. Uptake and biological effects of chitosancapped gold nanoparticles on ChineseHamster Ovary cells. Materials Science and Engineering C.31(2011) : 184189.

Burke, W.H., P. Licht, H. Papkoff, A. Bona Gallo. 1979. Isolation and characterization of luteinizing hormone and follicle-stimulating hormone for pituitary glands of the turkey (Meleagris gallopavo). Gen. Comp. Endocrinol. 37 : 508520.

Castro, G., N. Stoyan dan J. P. Nyers. 1989. Assimilation effi ciency in birds, a function of taxon and food type?. Comp. Biochem. Physiol. 92A ( 3 ) : 271-278.

Chen, T.F. 1996. Nutrition and feedstuffs of ducks. In: The Training Course for Duck Production and Management. Taiwan Livestock Research Institute, Monograph No. 46. Committee of International Technical Cooperation, Taipei.
Direktorat Jendral Budidaya Departemen Kelautan dan Perikanan, 2010. Djunaidi, I.H., T. Yuwanta, Supadmo dan M. Nurcahyanto. 2009. Pengaruh penggunaan limbah udang hasil fermentasi dengan Aspergillus niger terhadap performan dan bobot organ pencernaan broiler. JITV.14 ( 2 ): 104 - 109.

Dunn, I.C., Y. Chen, C. Hook, P.J. Sharp dan H.M. Sang, 1993. Characterizationof the chicken preprogonadotrophin-releasing

hormone-I gene. J. Mol. Endocrinol. 11 : 19-29.

Ikemoto, T. dan M. K. Park. 2005. Chicken RFamide-related peptide (GnIH)and two distinct receptor subtypes: identification, molecular characterization and evolutionary considerations. J. Reprod. Dev. 51( 3 ) : 359-377.

Imai, K. 1973. Effects of avian and mammalian pituitary preparations on induction of ovulation in the domestic fowl, Gallus domesticus. J. Reprod. Fertil. 33 : 91-98.

In, F. C., Z. A. Haiyee1, O. Hassan dan W. A. W. Mustapha. 2016. Nutritional composition and colour analysis of cholesterolreduced egg yolk powder. Malaysian Journal of Analytical Sciences. 20( 4 ): $820-826$.

Ketaren, P.P. 2007. Peran itik sebagai penghasil telur dan daging nasional. WARTAZOA. 17( 3 ) : $117-127$.

Khajarern, J. M., S. Khajarern, T. H. Moon dan J. H. Lee. 2003. Effects of Dietary Supplementation of Fermented Chitin-chitosan (FERMKIT)on Toxicity of Mycotoxin in Ducks.Asian- 
Australasian Journal of Animal Sciences. 16 ( 5 ) : 706 -713.

Khempaka, S., K. Koh dan Y. Karasawa. 2006. Effect of shrimp meal on growth performance and digestibility in growing broilers. J. Poult. Sci. 43: 250-254.

King, J.A., Millar, R.P., 1982. Structure of chicken hypothalamic luteinizinghormone-releasing hormone: II isolation and characterization. J.Biol. Chem. 257( 18 ) : 10729-10732.

Ottinger, M. A. dan M. R. Bakst. 1995. Endocrinology of the Avian Reproductive System. J. of Avian Med. Surgery.9(4):242 - 250 .

Palupi, R. 2005. Pengaruh Lama Pengukusan Limbah Udang yang Direndam Dengan Filtrat Air Abu Sekam Terhadap Kualitas Limbah Udang dan Pemanfaatannya pada Ayam Broiler. Tesis S2 pada Program Studi Ilmu Ternak Pascasarjana Universitas Andalas Padang.

Palupi R. dan A. Imsya. 2011. Pemanfaatan kapang Trichoderma viridae dalam proses fermentasi untuk meningkatkan kualitas dan daya cerna protein limbah udang sebagai pakan ternak unggas. Seminar Nasional Teknologi Peternakan dan Veteriner. Pusat Penelitian dan Pengembangan Peternakan, Badan Penelitian dan Pengembangan Pertanian, Departemen Pertanian, Bogor. Hal: 672-677.

Panjaitan, I., A. Sofiana dan Y. Priabudiman. 2012. Suplementasi tepung jangkrik sebagai sumber protein pengaruhnya terhadap kinerja burung puyuh (Coturnix coturnix japonica). J. Ilmiah IlmuIlmu Peternakan. 15( 1 ) : 8 -14.

Pratiwi, R. S., T. E. Susanto, Y. A. K. Wardani, A. Sutrisno. 2015. Enzim kitinase dan aplikasi di bidang industri: Kajian pustaka. J. Pangan dan Agroindustri.3( 3 ) : $878-887$.

Rahayu, L. H. dan S. Purnavita. 2007. Optimasi pembuatan kitosan dari kitin limbah cangkang rajungan (Portunus pelagicus) untuk adsorben ion logam merkuri. Reaktor. 11 ( 1 ) : 45 - 49.

Saenab, A., E. B. Laconi, Y. Retnani, dan M. S. Mas'ud. 2010. Evaluasi kualitas pelet ransum komplit yang mengandung produk samping udang. JITV. 19( 3 ) : 31 $-39$.

Sahara, E. 2010. Pengaruh Pemberian Daun Kaliandra (Calliandra calothyrsus) dan Kepala Udang terhadap Keamanan Organ Dalam Ternak Itik. Jurnal Sain Peternakan Indonesia, 5(2). 95 104.

Scanes, C. G. 2006. Sturkie's Avian Physiology Sixh Edition. Elsevier. UK.

Suryaningsih, L dan A. Parakkasi. 2006. Pengaruh Pemberian Tepung Cangkang Udang (Karapas) sebagai sumber khitin dalam ransum terhadap kadar LDL (Low Density Lipoprotein), HDL (High Density Lipoprotein), dan persentase karkas (Effects of Shrimp Shell Mills as Chittin Source on LDL (Low Density Lipoprotein), HDL (High Density Lipoprotein) of Meat and Carcass Percentage). J. Ilmu Ternak. 6( 1 ) : $63-67$. 
Tilly, J. L. dan A. L. Johnson. 1989. Regulation of androstenedione productionby adenosine 3,5monophosphate and phorbol myristateacetate in ovarian thecal cells of the domestic fowl. Endocrinology. 125:1691-1699.

Tilly, J.L., K.I. Kowalski danA.L. Johnson1991. Cytochrome P450 sidechain cleavage $(\mathrm{P} 450 \mathrm{scc})$ in the hen ovary. II P450scc messenger RNA, immunoreactive protein, and enzyme activity in develop ing granulosa cells. Biol. Reprod. 45 : 967-974.

Yuwanta, T. 2003. Dasar Ternak Unggas. Kanisius. Yogyakarta. 